Tér és Társadalom 20. évf. 2006/2. 143-146. p.

Tér és Társadalom

XX. évf. 2006

2: $143-156$

\title{
KÖNYVJELZÖ
}

\section{KOCSIS KÁROLY (SZERK.): DÉLKELET-EURÓPA TÉRKÉPEKBEN}

\author{
(MTA Földrajztudományi Kutatóintézet, \\ Kossuth Kiadó, Budapest, 2005, 99 o.)
}

\section{VATI TAMÁS}

A kỏnyv nyolc fejezetben, nagyszámú és kitủnően szerkesztett didaktikai apparátus ( $53 \mathrm{db}$ ábra és $18 \mathrm{db}$ táblázat) és szỏveges elemzés során tárja fel Délkelet-Európa társadalmi, gazdasági jellegzetességeit és 20. századi fejlődésének legfontosabb szegmenseit.

A bevezetô fejezetben sor kerül - az egyébként gyakran egymás szinonimájaként használatos - a Balkán és Délkelet-Európa fogalmi és területi lehatárolására. Elóbbi szůkebb, utóbbi tágabb téregységet jelöl. A szerző megemlíti azt is, hogy a „balkán" kifejezés napjainkban negatív jelzőként használatos. Az elmaradottság, a korrupció, a zürzavar és az etnikai alapú regionális destabilizálódás rokon kifejezéseként él a köztudatban.

A történelmi események ismeretének hiányában a térség megértése szinte lehetetlen. A szerző ezt szem elött tartva alaposan szemlélteti Délkelet-Európa múltjảnak legjelentösebb történéseit, kủlönös hangsúlyt fektetve a 20 . század eseményeire. A fejezet rávilágít arra az egész múvỏn végigvonuló felismerésre, hogy három politikaitörténeti időszak következményei alakították ki a régió mai etnikai-vallási arculatát.

A 14-16. században bekövetkezett oszmán hódítás idején az addig viszonylag stabil etnikai térszerkezet a tömegméretũ migrációk következtében felbomlott. DélkeletEurópa az egész kontinens legtarkább etnikai területévé vált. Az I. világháborút lezáró békeszerződések, bár nemzetállamok megvalósítását tủzték ki célul, soknemzetiségü kisállamokat hoztak létre. A korabeli nagyhatalmi érdekek ezzel olyan mértékú feszültségeket teremtettek, melyek megoldása máig nem sikeruilt. A Szovjetunió felbomlása robbanásszerủen hozta felszínre a térség minden országában a múltból örökölt vallási-etnikai feszültségeket, melyek az 1990-es évek délszláv háborúiban csúcsosodtak ki. A határok menti nemzeti kisebbségek által elképzelt etnikaiterületi autonómiák további lehetséges veszélyforrást jelenthetnek. A régió vallási térszerkezete a háborús etnikai tisztogatások, to̊meges migráció és asszimiláció következtében kialakult etnikai viszonyoknak megfelelően alakult.

Az urbanizációt és városhálózatot vizsgáló részegységbỏl kiderül, hogy DélkeletEurópa - elsỏsorban a balkáni államok - urbanizációs szintje jelentősen elmarad az 
európai átlagtól. A városlakók aránya 40-50\% körüli. A városfejlődés két fontos időszaka, a szocializmus negyven éve és a délszláv háborúk utáni tíz esztendő kerül részletezésre. A kommunista hatalomátvételt követően a balkáni államok urbanizációja felgyorsult, s az államszocialista időszak során a korábbinál mindvégig gyorsabb ütem jellemezte (ideológiai okok, migráció). Az 1990 utáni időszakban a városok nem vagy csak igen kis mértékben növekedtek (háború, ipari munkahelyek leépülése, külföldre vándorlás) és egyedül a korábbi nagyvárosok súlya nőtt meg.

A gazdaságot érintö négy fejezet első tagja az államok gazdasági fejlettségi szintjét és térbeli eltéréseit mutatja be. Miután a szerző felvázolja azokat a történeti folyamatokat, melyek évszázadokon keresztül hátrányosan érintették a gazdaság fejlödését, a vizsgált 8 ország jelenlegi gazdasági erejét szemlélteti a GDP és GNP mutatók alapján. Az egyes országokon belüli regionális különbségek részletezésére azért sem kerül sor, mert a különbségek nem számottevőek, az alacsony fejlettségi szint az országok egészére érvényes. A jövöt illetően kedvező helyzetben az Európai Uniós tagsághoz közel állók vannak, míg a most is fejletlennek számító államok esetében marad az elmaradottság és a teljes elzárkózás.

A Balkán országainak iparában is kísért a múlt, ismétlödnek a múlt eseményei, ha más formában és más körülmények között is. Iparának megújulása jóval később kezdödött és lassabban haladt, mint a közép-kelet-európai országoké. Abban az esetben, ha hozzávesszük a jellemzö balkáni tendenciákat (a háborúkban megmaradt üzemek nem élet- és versenyképesek; dezindusztriális folyamatok; privatizáció nehézkesen zajlott és zajlik; a külföldi töke csak 1995 után érdeklödik a terület iránt) érhetövé válik, hogy miért nem értek el olyan látványos eredményeket. Az elörelépés szempontjából mindenekelőtt a lokális politikai helyzetet és a lokális társadalmi környezetet kell vonzóvá tennie az országoknak. Az ipar súlya alapján két kategóriába sorolja a régió országait. Az egyikbe a jelentős iparral nem rendelkezök, a másik csoportba azok az országok sorolhatók, amelyek gazdaságában a csökkenỏ súlya ellenére is fontos szerepe van a szekunder szektornak.

A régió országainak gazdasági kapcsolatában kiemelt szerepe van a közlekedésnek. Annak ellenére, hogy a közlekedési hálózat kiépítése Európához képest jócskán megkésett, az EU-csatlakozás lehetősége a balkáni országok vasút- és közúthálózati szerepét is jelentősen felértékelték. Egy Nyugat-Európa/Közép-Európa Törökország/Közel-Kelet relációban a térségnek komoly érdeke lenne. A vízi közlekedésben rejlő lehetőségek mérsékeltebbek. A balkáni országok kikötői az európai tengerhajózási térben periférikus helyzetü peremtengerek mentén helyezkednek el, és tengerpartjaik Horvátország kivételével rövidek. A folyami hajózás legnagyobb problematikája, hogy a Duna kevés gazdaságilag jelentỏs térséget érint. A polgári légi közlekedés a fővárosok kapcsolattartása (kivételt Szerbia jelent) mellett a szárazföldi közlekedés számára nehézséget okozó természeti akadályok (pl.: Kárpátok) leküzdésére szolgál.

A gazdaság legdinamikusabban fejlödő szegmense egyértelmủen a turizmus. Mind a jelenben, mind a jövőben a nemzetközi turistaforgalom potenciális célterületét jelenti. Horvátország és Szlovénia európai szinten is magas szolgáltatást nyújtó 
és jelentős vendégforgalmat bonyolít le. A közeljövöben csak Románia és Bulgária felzárkózása lesz elképzelhetö, míg a többi állam komoly hendikeppel indul a térségbe érkező turistákért folyó versenyben. Nagy hátránya a térségnek, hogy Európán kívüli turista (a háborúk, közel-keleti térség kơzelsége miatt) csak a legritkább esetben látogat el a területre. Az idegenforgalom jövőképe mindenesetre kedvezö.

Összességében elmondható, hogy a szerzők a legújabb és nagyszámú szaktudományi ismeretek felhasználásával alkottak. Délkelet-Európa minden egyes országa minden fejezetben előkerül. Albánia, Bulgária Bosznia-Hercegovina, Horvátország, Macedónia, Románia, Szerbia és Montenegró, valamint Szlovénia társadalmi és gazdasági jellemzői alaposan kielemeztetnek, annak múltra visszavezethető okaival és a várható jövőképpel együtt. Hiányérzete az olvasónak abban lehet, hogy a könyv nem tesz említést a primer szektorról (mezőgazdaság), pedig vannak olyan országok (pl.: Albánia), ahol a mezőgazdaság dominál az ágazatok közül. A könyvszerü atlasz kitünően alkalmas arra a szerepre, melyre szánták, vagyis a közvélemény, a tudós társadalom és a politikai döntéshozók gyors tájékoztatására.

Ajánlom a könyvet a Balkán országai, a földrajz iránt érdeklődőknek, illetve a leendő kőnyvszerkesztőknek (hogy lássák, a gazdag illusztráltság mennyivel élvezetesebbé teheti a száraz tényanyagot). 
Tér és Társadalom 20. évf. 2006/2. 143-156. p.

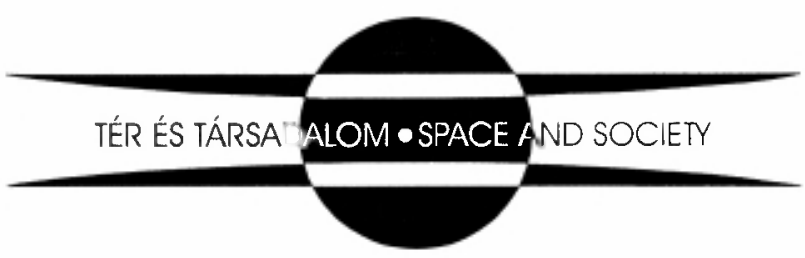

